\title{
Fertilization in Lilium.
}

\author{
BY \\ V. H. BLACKMAN, Sc.D., F.L.S.,
}

AND

E. J. WELSFORD, F.L.S.

With Plate XII.

ATHOUGH the process of fertilization in the higher plants has received much attention we are still surprisingly ignorant of many of its important physiological and anatomical details. The behaviour and function of the synergids, the nature of the mechanism by which the two male nuclei reach their respective goals, the exact relation of the pollen-tube to the embryo-sac and the manner of the tube's opening, the stage at which vermiform nuclei first take on their peculiar shape, are all problems which require further investigation. What important results are to be obtained by a careful study of a few forms is shown by Nawaschin's ${ }^{1}$ investigation of Fritillaria tenella, Fuglans nigra, and Helianthus annuus. He shows how different are the details of fertilization in these three forms, and brings forward very convincing evidence for the view that, in these cases at least, the male nuclei are motile, making their way through the embryo-sac by their own activity.

The observations here briefly described are the result of the investigation of some material originally intended for class-work. Portions of ovaries of Lilium Martagon were fixed in the summer of 1907 and put on one side. When examined later it was found that the fixation was extremely good, and that some of the material had been caught at a very fortunate stage. The quality of the material is shown by the fact that on one slide no less than twenty-two triple fusions were to be observed, and in many of the same ovules the fusion of the male and female nuclei could also be seen.

1 Ueber das selbständige Bewegungsvermögen der Spermakerne bei einigen Angiospermen. Österreich. botan. Zeitschr., lix, 1909, p. 457 .

[Annals of Botany, Vo1. XXVII. No. CV. January, 1913.] 
This led to a close examination of the material, and later similar material was obtained of Lilium auratum; and material of Petunia violaceae was also collected for comparative observations of a Dicotyledon. As this work has been interrupted before completion it seemed worth while to publish figures and a brief description of the results obtained in Lilium; for it is a surprising fact that while L. Martagon was one of the first forms in which triple fusion was observed, yet there exist no really satisfactory figures even of the more obvious details of fertilization of that form. Guignard's well-known illustrations, though sufficient for demonstration, are only text-figures and leave much to be desired.

One of the points which our figures bring out clearly is the complete absence of male cells even at the stage in which the nuclei have only just left the pollen-tube (Pl. XII, Fig. 5). In fact Nawaschin ${ }^{1}$ has recently shown that the cytoplasm of the generative cell is lost in the general cytoplasm of the pollen-tube at the time that its nucleus gives origin to the male nuclei.

In all cases the male nucleus fusing with the polar nuclei is somewhat larger and more contorted than that which fuses with the female nucleus. The figures here published show more clearly than earlier ones the form and structure of the male nuclei of Lilium. When the male nuclei have just entered the embryo-sac, but are still surrounded by the contents of the pollen-tube (Fig. 5), the vermiform character is very apparent, and the chromatin, though not of an ordinary resting type, yet shows a network. ${ }^{2}$ At a later stage (Figs. I and 6) the chromatin stains more deeply and begins to be arranged in threads. Later on (Figs. $2 a, 2 b, 2 c$ ) the chromatin threads are very thick and distinct. Nawaschin associates these signs of activity in the chromatin with the self-motility of the male nuclei, but it is possible that it is a mere preliminary to fusion or to the subsequent division of the fusion-nucleus, for, as Fig. 4 shows, the chromatin of the female nucleus sometimes becomes thread-like immediately before fusion.

Our studies of these two species of Lilium have led us to the view, held by Nawaschin for the forms he has studied, that the male nuclei have the power of movement, and by their own activity make their way to the nuclei with which they fuse. The shape of the nuclei, understandable if the nuclei have to push or writhe their way through cytoplasm, would seem quite unsuitable to their carriage by strands of cytoplasm. We have further been able to make out that in many cases the polar male nucleus is distinctly more pointed at one end, and sometimes this difference between the ends is very marked (Figs. $2 a, 2 b, 2 c$ ), though it has not been possible

1 Nawaschin, S. : Näheres über die Bildung der Spermakerne bei Lilium Martagon. Annales du Jard. Botan. de Buitenzorg, $2^{\mathrm{e}}$ sér., Suppl. iii, I910, 87 I-904.

${ }^{2}$ In this our observations do not agree with those of Nawaschin (I9I0, loc. cit.), who states that in L. Martagon the male nuclei do not pass into the resting state, but the chromatin retains the arrangement characteristic of the telophase of the last division. His observations appear, however, to be based on studies of the pollen-tube outside the embryo-sac. 
to show that the pointed end moves first. Figs. $2 a$ and $2 c$ do certainly suggest very strongly a capacity for progression by creeping or some undulatory movement. Nawaschin has already pointed out the difficulty of accepting the view that two separate currents of cytoplasm take the nuclei as they lie close together and carry them in opposite directions. Some chemotactic relation between the approaching nuclei would seem to be a necessary assumption, for, as Nawaschin points out, it is only the male nuclei which are so carried-other granular bodies which accompany them into the embryo-sac remain behind. In Fritillaria, and perhaps in Lilium though we were unable to elucidate this point, the contents of the pollentube pass, not into the cytoplasm of the embryo-sac, but into a space between the cells of the egg-apparatus, above, and the cytoplasm of the polar nuclei, below.

It is to be noted that even at the earliest stage in which the male nuclei have been observed in the embryo-sac there is a distinct difference in their size (Fig. 5), the forward ones being narrower and smaller. As the nucleus in contact with the female cell is generally smaller than the one in contact with the polar nuclei it is probably the one which lies towards the apex of the pollen-tube which fertilizes the egg-cell (compare Figs. I and 5).

In the contents of the pollen-tube after their entry into the embryo-sac two very deeply staining bodies are to be seen (Figs. 5 and 6 ) ; these are of doubtful nature and correspond to the X-Körper of Nawaschin. Also in Fig. I there is a band-like structure which stains deeply with safranin and li es just below the female cell and almost in contact with the lower male nucleus. There are also three other fragments of a similar nature lying close by. Are these possibly the remains of an abortive blepharoplast or cilia-bearing band?

The material was fixed in Flemming's strong fluid, and as the sections were mostly thick for convenience of examination, they were stained deeply in safranin, washed out with alcohol, and then treated with Lichtgrün dissolved in clove oil. By this means a very transparent stain is obtained, enabling one to examine with ease sections so thick ( $20 \mu$ or more) that they would be completely obscured by the use of gentian-violet.

\section{EXPLANATION OF PLATE XII.}

Illustrating Professor Blackman's and Miss Welsford's paper on Fertilization in Lilium.

Fig. I. Section of the ovule of Lilium Martagon at time of fertilization. The two male vermiform nuclei are well seen, also the egg and the synergid. A deeply staining band and other bodies are to be seen below the female nucleus. $\times 680$. 


\section{4 Blackman and Welsford.-Fertilization in Lilium.}

Fig. 2. $a$ and b. L. Martagon; $c, L$. auratum. Male nuclei of various shapes in contact with polar nuclei. The contrast between the 'active' chromatin of the male nuclei and the 'passive' chromatin of the polar nuclei is very striking. $\times 1,260$.

Fig. 3. L. Martagon. Later stage of union of male and polar nuclei; the male nucleus has shortened and thickened and has lost its vermiform appearance. $\times 1,260$.

Fig. 4. L. Martagon. Male nucleus in contact with egg at a later stage than that shown in Fig. I. The chromatin of the female nucleus now shows a spireme like that of the male. $\times 1,720$.

Fig. 5. L. auratum. Very early stage of entry of male nuclei into the embryo-sac. The main mass of the material round the nuclei apparently represents the contents of the pollen-tube which has only very recently destroyed the synergid. Even at this early stage there is a distinct difference in size between the two nuclei. The two deeply staining bodies represent the X-bodies of Nawaschin. \& 1,100 .

Fig. 6. L. auratum. A slightly later stage than that of Fig. 5. It shows the remains of the contents of the pollen-tube, with the X-bodies, the two male nuclei, and the egg-cell with the nucleus of the undestroyed synergid above it. $\times \mathrm{I}, \mathrm{I} 00$. 
Annals of Botany

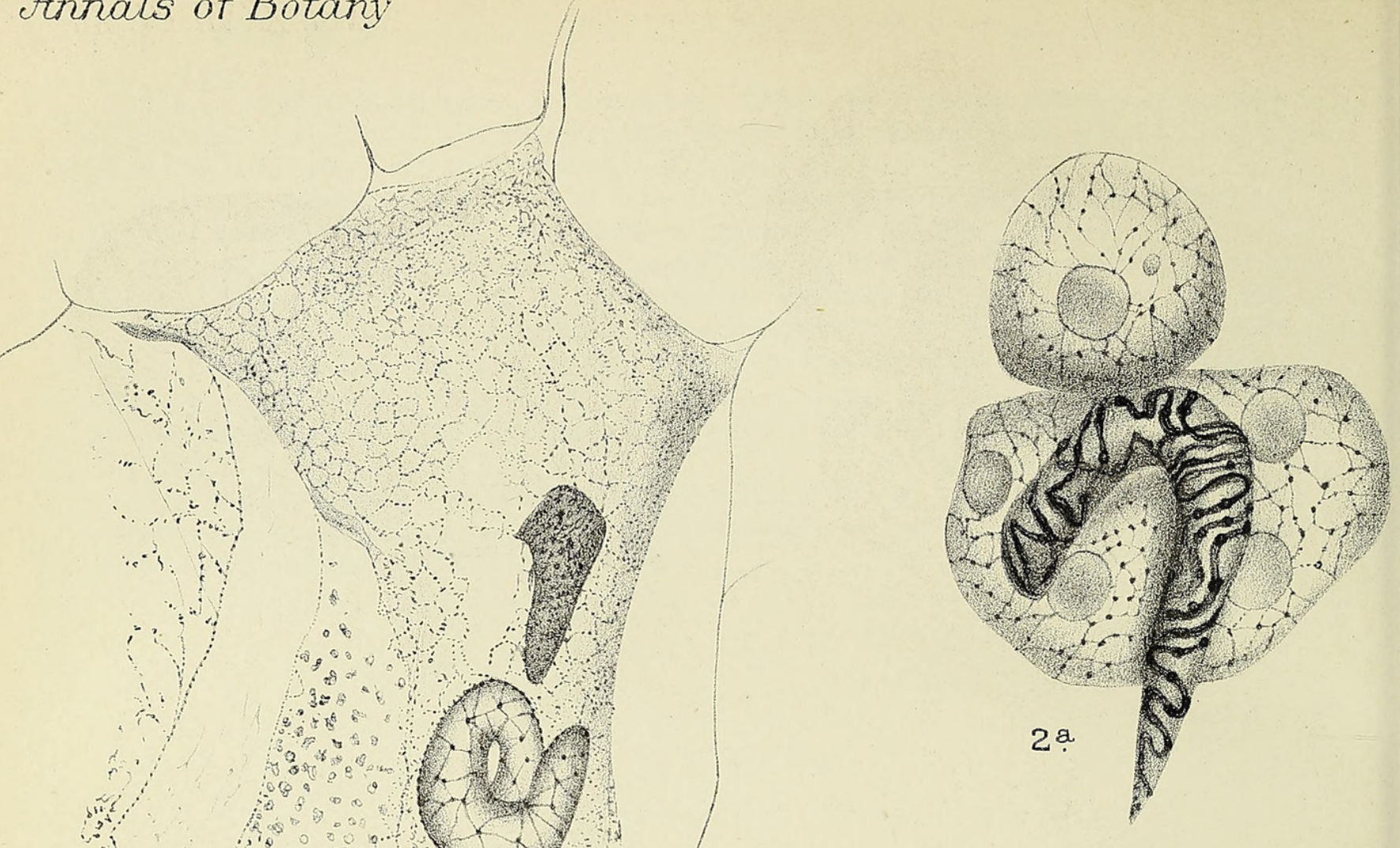

5.

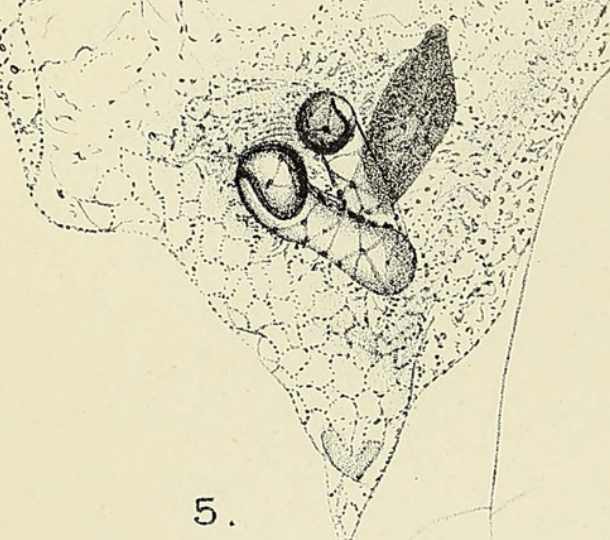

5
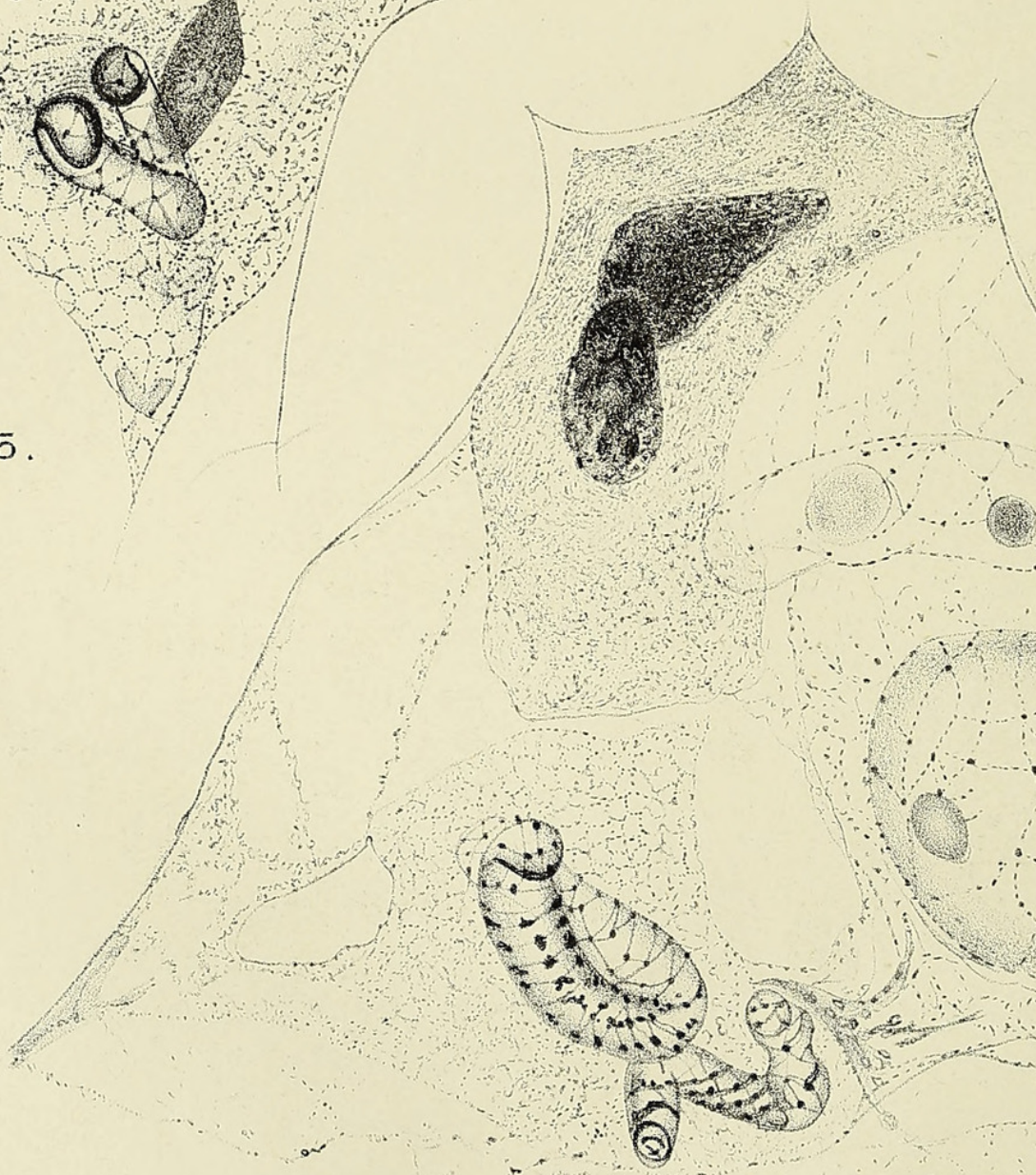


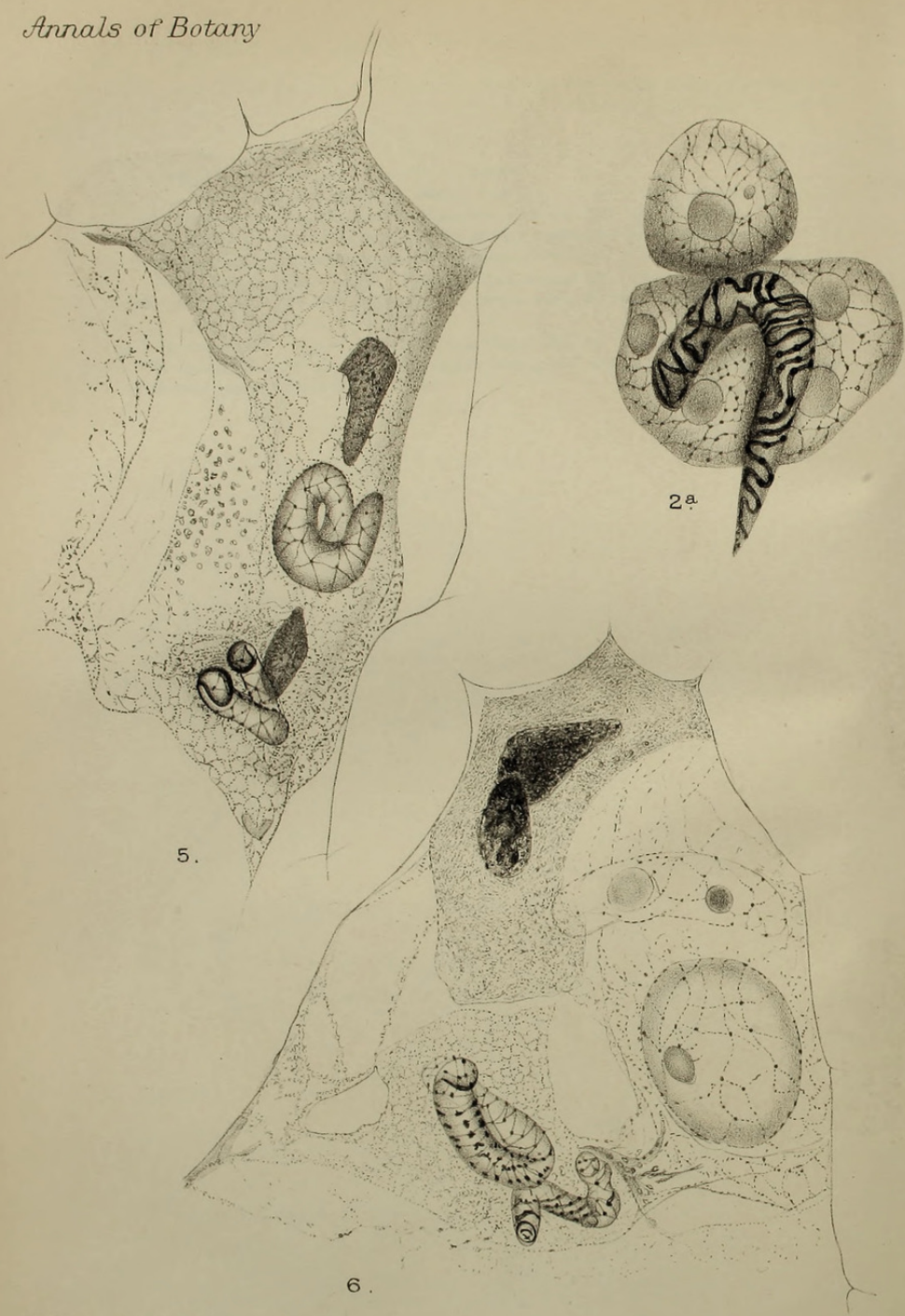

Vol. XXVII, PL.XII.

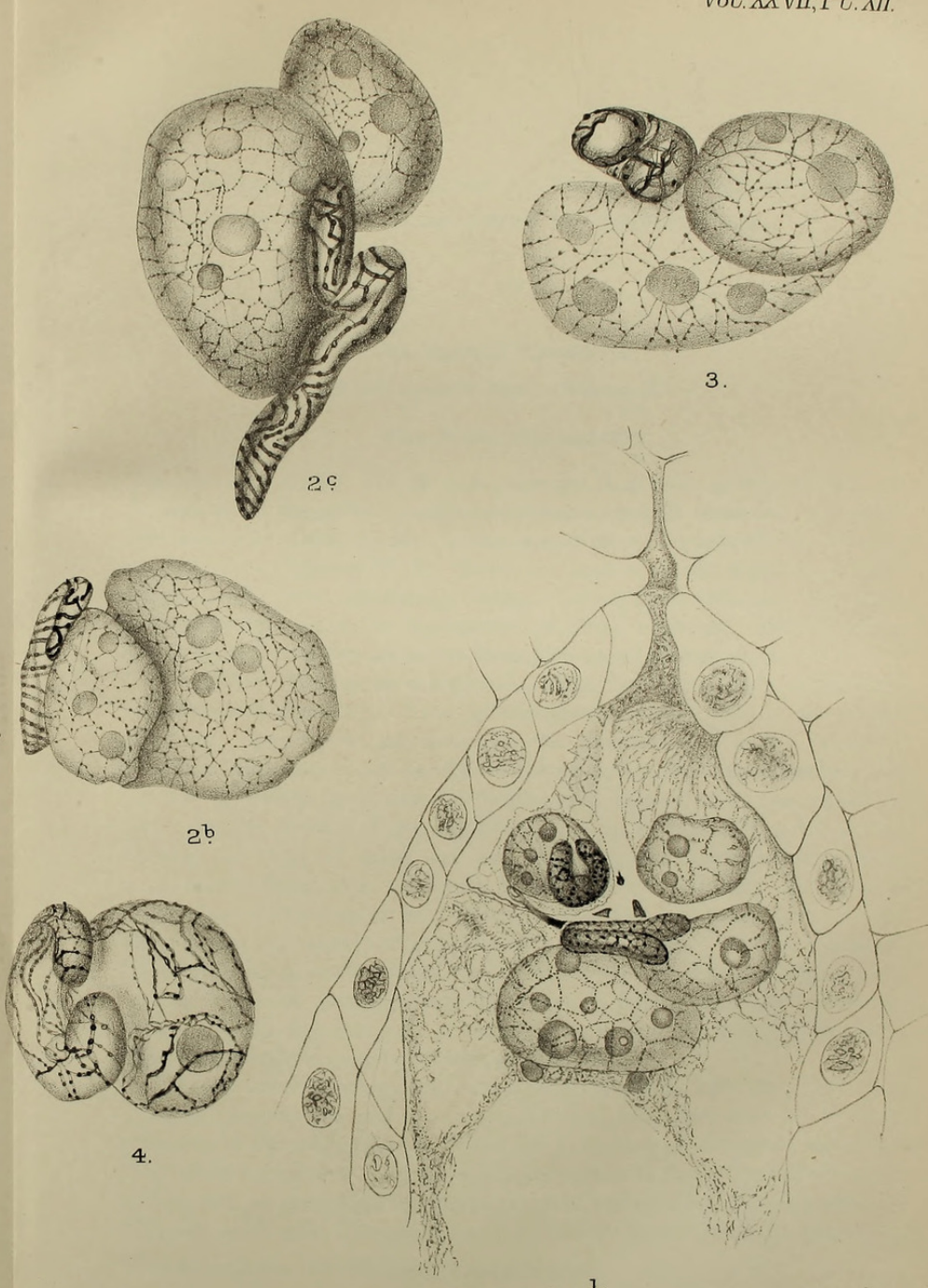

BLACKMAN AND WELSFORD-LILIUM. 


\section{$2 \mathrm{BHL}$ Biodiversity Heritage Library}

Blackman, Vernon H. and Welsford, E. J. 1913. "Fertilization in Lilium." Annals of botany 27, 111-114. https://doi.org/10.1093/oxfordjournals.aob.a089444.

View This Item Online: https://www.biodiversitylibrary.org/item/237410

DOI: https://doi.org/10.1093/oxfordjournals.aob.a089444

Permalink: https://www.biodiversitylibrary.org/partpdf/319960

\section{Holding Institution}

Smithsonian Libraries

\section{Sponsored by}

Biodiversity Heritage Library

\section{Copyright \& Reuse}

Copyright Status: Not in copyright. The BHL knows of no copyright restrictions on this item.

This document was created from content at the Biodiversity Heritage Library, the world's largest open access digital library for biodiversity literature and archives. Visit BHL at https://www.biodiversitylibrary.org. 